\title{
FINANCIAL DEFICIENCY SYNDROME AND BEHAVIOUR OF LOW INCOME EARNERS IN RURAL COMMUNITIES OF RIVERS STATE, NIGERIA
}

\author{
Dr. Henry Waleru Akani, \\ Department of Banking and Finance, \\ Rivers State University \\ Nkpolu - Port Harcourt, Rivers State, Nigeria \\ Anyike Lucky \\ Department of Banking and Finance, \\ Rivers State University \\ Nkpolu - Port Harcourt, Rivers State, Nigeria
}

\begin{abstract}
This study examined the effect of financial deficiency on the behavior of low income earners in rural communities of Rivers State. The objective was to examine how financial deficiency affects the behavior of low income earner. One hundred respondents were selected from the 10 local governments in Rivers State. Questionnaire were designed and administered to the respondents in the local governments. Descriptive analysis and Pearson Product Correlation Coefficient with the aid of Statistical Package for Social Sciences was used as data analysis. Findings revealed that financial deficiency have positive effect on the behavior of low income earners in rural communities of Rivers State. The study recommends that government should formulate policies that will reduce unemployment in rural communities, the needs to increase public awareness on financial inclusion in the rural communities. Efforts should be advanced by the government to reduce financial exclusion in the rural communities of rivers state and the regulatory authorities should ensure equitable distribution of financial institutions and financial servicing to the rural communities in Rivers State.
\end{abstract}

KEYWORDS: financial deficiency syndrome, behaviour, low income earners, rural communities, Rivers State, Nigeria

\section{INTRODUCTION}

Financial deficiency syndrome relates individual financial condition where financial indicators such as income are far below expenditure. It is characterized by unemployment, financial exclusion, spiritualism and inadequate financial awareness. Inadequate finance does not only affect negatively behavior of low income earners but have the capacity to induce the person to crime. Individual financial immune deficiency can affect emotional well, mental wellbeing, health and socio-cultural wellbeing.

The important of money cannot be underestimated in human life; money is an essential commodity that helps you run your life. Exchanging goods for goods is an older practice and without any money, you cannot buy anything you wish. Money has gained its value because people are trying to save wealth for their future needs. Money cannot buy everything but practically money is the basic thing that is used for calculating the status of any person and 
therefore its deficiency has significant effect on human existence. The bible acknowledged that money is the answer to everything in life. The function of money as a medium of exchange makes it a convenient asset to hold, because it enables the holder to avoid the time and effort which would otherwise have to be involved in synchronizing market exchanges (Noble, Houston, Kan and Sowell, 2012). Convenience, particularly where it involves time saving, is something of a luxury. For this reason one might expect the demand for money, to provide such services, to rise by more than in proportion to the growth of real per capita incomes.

The concept of financial deficiency relates to the inability of house hold income to finance and carter for the financing needs of the person it can also be seen as situation where financial liability is greater than income of the person or the depreciating value of income due macroeconomic factors such as inflation and other macroeconomic instability. Banerjee (2000) detailed theoretically that poverty might change behavior either by making the poor desperate, or by leaving them vulnerable. Irving Fisher (1930) detailing his Theory of Interest, explains that a small income, other things being equal, tends to produce a high rate of impatience. This is both rational immediate survival is necessary to enjoy any future income or utility at all and irrational the effect of poverty is often to relax foresight and self-control and to tempt us to 'trust to luck' for the future. Like corporate organizations, individual needs to be financially adequate to meet their financing needs such as food, shelter and cloths. Inadequate financial resources deny peoples these basic amenities which make one to have emotional and mental bad feelings.

It also allows them to avoid, or ameliorate, potentially harmful toxins for example living in poor neighborhoods that are noisy or polluted (Banerjee, 2000). This implies a basic level of financial resources is required for good health, but evidence suggests that there is a much more graded association: the more money people have the better their health, better emotional and mental reasoning and better socio-economic and socio-cultural wellbeing (Racz, McMahon \&Luthar, 2011). The context in which people live will influence the extent to which money may influence behavior for example, in well developed welfare systems, the health-damaging effects of income losses resulting from unemployment or family breakdown reduced by the availability of welfare benefits.

Evidence about the association between income and behavior, both at one point in time and over time, can be found in a wide range of disciplines. However, there is much debate about the specific causal pathways that link people's income and behavior and the two key concepts income and behavior are both defined and measured in a wide range of ways. Given this complexity, a systematic theoretical review has been conducted to develop a better understanding of how income and behavior are related over the life course. Significant proportion of the studies are foreign studies, similar studies in Nigeria (Racz, at al, 2011; Mani, Mullainathan, Shafir, \& Zhao, 2013; Hackman, Betancourt, Brodsky, Kobrin, Hurt \& Farah, 2013) examined the effect of poverty and income inequality on Nigeria household. Therefore this study examined the effect of immune financial deficiency syndrome on the behavior of low income earner of rural communities in Rivers State. 


\section{LITERATURE REVIEW\#}

\section{Financial Immune Deficiency Syndrome}

Financial immune deficiency syndrome refers amount left over when the money realized from the sale of a foreclosed property is insufficient to pay off the full loan amount. This is one of the reasons banks usually insist on the borrower's personal guaranty so that they can go after his or her home or other property to make up the shortfall. The amount due on a mortgage loan after adding all expenses of foreclosure and accrued interest to the principal balance of the loan and then deducting the sale price or lender-bid price for the property, the balance remaining, if any, may be collected by the lender by means of taking a deficiency judgment, unless prohibited by law or contract.

\section{Unemployment}

The concept of unemployment According to Balami (2006) unemployment is conceptualized as a situation where in a worker is or workers are involuntarily out of work. This means that workers are willing and able to work but cannot find any work. Unemployment has been defined by the classical economists as the excess supply of labour over the demand for labour which is cause by adjustment in real wage. The Classical or real-wage unemployment occurs when real wages for job are set above the market-clearing level, causing number of job-seekers to exceed the number of vacancies. Unemployment was defined by International Labour Organization (2009) as a state of joblessness which occurs when people are without jobs and they have actively sought work within the past four weeks. The unemployment is a measure of the prevalence of unemployment and it is calculated as a percentage by dividing the number of unemployed individuals by individuals currently in the labour force. In a 2011, Business Week Reported, "More than two hundredmillion (200) people globally are out of work, a record high, as almost two-third of advanced economies and half of developing economies are experiencing a slowdown in employment growth.Jhingan (2001) unemployment can be conceived as the number of people who are unemployed in an economy, often given as a percentage of the labour force.

11Unemployment was also defined as numbers of people who are willing and able to work as well make themselves available for work at the prevailing wage but no work for them. According to Aminu and Anono (2012) Unemployment can be conceptualized as total number of people who are willing and able to work, and make themselves available for job at the prevailing wage but no work for them. This therefore, implies that unemployment is a state of joblessness in the country.

\section{Financial Inclusion}

Financial inclusion is where individuals and businesses have access to useful and affordable financial products and services that meet their needs that are delivered in a responsible and sustainable way. Financial inclusion is defined as the availability and equality of opportunities to access financial services. Those that promote financial inclusion argue that financial services can be viewed as having significant positive externalities when more people and firms participate. One of its aims is to get the unbanked and unbanked to have better access to financial services. The availability of financial services that meet the specific needs of users 
without discrimination is a key objective of financial inclusion (Samargandi, Fidrmucand Ghosh, 2013). For example, In the United States this condition represents a third of the Hispanic community born in America and half the foreign Hispanic community living in the United States remain unbanked. For this example, give financial services is key in order to growth as a society. There is some scepticism from some experts about the effectiveness of financial inclusion initiatives. Research on microfinance initiatives indicates that wide availability of credit for micro-entrepreneurs can produce informal intermediation, an unintended form of entrepreneurship.

\section{Financial Literacy}

Financial literacy is an essential life skill that has important impact on individual, family wellbeing and on the broader economy. Over the past two decades, both developedand developing countries have become increasingly concerned about the level of financial literacy of their citizens, particularly among young people. Moreover, the literature suggest that, globally, financial illiteracy is a major reason forfalling saving rates (Hilgert et al., 2003), mounting consumer debt (Stango\&Zinman, 2007), inadequate planning for retirement (Lusardi\&Mitchell, 2011), basis for divorce, poor mental health and a variety of other negative and unhappy experiences (Kinnunen\&Pulkkinen, 1998), the cause of emotional stress, depression and lower self-esteem (Wolcott \&Hughes, 1999). This has led to the recognition that better financial literacy skills could contribute to improved financial decision making, and that these decisions could, in turn, have positive effects not only on households but also on economic and financial stability of a country more generally (OECD/INFE, 2017). Indeed, the acquisition and development of financial literacy skills among young people is increasingly perceived by policy makers as essential for several reasons.

\section{Human Behavior}

Human behavior refers to the array of every physical action and observable emotion associated with individuals, as well as the human race. While specific traits of one's personality and temperament may be more consistent, other behaviors will change as one moves from birth through adulthood. In addition to being dictated by age and genetics, behavior, driven in part by thoughts and feelings, is an insight into individual psyche, revealing among other things attitudes and values. Social behavior, a subset of human behavior, studies the considerable influence of social interaction and culture. Additional influences include ethics, encircling, authority, rapport, hypnosis, persuasion and coercion.

The behavior of humans (and other organisms or even mechanisms) falls within a range with some behavior being common, some unusual, some acceptable, and some beyond acceptable limits. In sociology, behavior in general includes actions having no meaning, being not directed at other people, and thus all basic human actions. Behavior in this general sense should not be mistaken with social behavior, which is a more advanced social action, specifically directed at other people. The acceptability of behavior depends heavily upon social norms and is regulated by various means of social control. Human behavior is studied by the specialized academic disciplines of psychiatry, psychology, social work, sociology, economics and anthropology. 


\section{Low Income Earners}

This is primarily comprised of lower-level citizens, white-collar workers. These workers are typically not educated and lack the graduate degrees needed to advance to higher levels of employment, or have a degree but remain unemployed but manage to put food on its table. Income for these workers generally falls between N160,500 and N200,000. This category is trapped in the poverty rate of $69 \%$ of the total population. According to Nigeria Bureau of Statistics report 2018, inequality in Nigeria worsened between 2004 and 2013 but improved in 2016 using either the gini coefficient or the Inequality as measured by the Gini worsened from 0.356 in 2004 to 0.41 in 2013 but improves to 0.391 in 2016 . Using the, inequality worsened from 0.217 in 2003 to 0.395 in 2013 but improved to 0.31 in 2016. With respect to consumption shares (and using consumption as a proxy for income), in 2004, the bottom 10\% (poorest of the poor) of the population consumed $2.56 \%$ of goods and services, while the top $10 \%$ (super rich) consumed $26.59 \%$ of all goods and services. The richest $10 \%$ were responsible for $26.59 \%$ of national expenditure or income in 2016.

This increased to $33.72 \%$ in 2013 but decreased to $31.09 \%$ in 2016 . The top $20 \%$ were responsible for $42.40 \%$ of national income/expenditure in 2004 . This increased to $48.28 \%$ in 2013 but declined to $46.63 \%$ in 2016 . While no agreed standard definition of the Nigerian middle class exists, for the purpose of this report we have classified decile 01-03 as the lower class, decile 04-07 as the middle class and decile 08-10 as the upper class. Accordingly, the upper class was responsible for $58.39 \%$ of national income/expenditure down from $59.42 \%$ in 2013. The share of the upper class in national income had been rising between 2004 and 2013 before reducing in 2016. The middle class on the other hand accounted for $30.26 \%$ of national income/expenditure in 2016, higher than $29.14 \%$ in 2013 . The share of the middle class had been declining between 2004 and 2013 in favor of the higher class but that reversed in 2016. Finally, the lower class accounted for $11.35 \%$ of national income/expenditure in 2016 lower than $11.43 \%$ in 2013.the biggest gainers of income/expenditure shares between 2013 and 2016 has therefore been the middle class, while the lower-class share remained constant while the high- class shares reduced. This widening gap between the rich and the poor in Nigeria is contrary to Kuznets' hypothesis.

\section{Socio-Cultural Behavior}

Financial welfare of low-income earners has been a longstanding issue for policy makers. Substantial empirical evidence demonstrates that financial hardship is related to adverse health, academic, behavioral, and social outcomes for children (Duncan and Brooks-Gunn 1997). These results have implications for the intergenerational transmission of poverty as children who grow up in low-income families have poorer academic outcomes and poorer economic prospects. Research on economic wellbeing and children's socio-emotional outcomes has generally focused on measures of income and poverty and finds a relationship (Blau 1999, Shea 2000, Maurin 2002, Morris and Gennetian 2003, Taylor, Dearing, and McCartney 2004, Berger, Paxson, and Waldfogel 2009). Only one study has investigated the relationship between material hardship (going without basic necessities such as food or shelter) and child socio-emotional behaviors (Gershoff, Aber, Raver and Lennon 2007). Although this study suggests that material hardship would affect child socio-emotional development, more research is needed to understand whether hardship is detrimental to child behavior and if there are 
specific types of hardship that are particularly harmful. Programs that target material hardship may be able to help diminish the incidence of socio-emotional problems in low income families and assist in reducing the transmission of poverty between generations. In this paper we extend previous research on material hardship and behavior in several ways.

The family stress model also suggests that increases in material hardship will likely increase child behavior problems and decrease child positive behavior. Financial hardship or pressure can eclipse parents'socio-emotional resources and disrupt parent-child interactions (Conger and Conger 2000). For example, decreased parental supervision, increased usage of harsh parenting or increased parental depression or anxiety as a result of experiencing material hardships may in turn affect child behavior. Existing research provides some empirical support for both hypotheses. Gershoff, Aber, Raver and Lennon (2007) look at the effect of material hardship and income on 6 and 7 year old children's emotional and cognitive skills using structural equation modeling. Their analyses look at mediating pathways (parenting quality, stress, and investment) between income and material hardship and child behavior. In support of the family stress model, they find that income and material hardship affect parenting stress and investment which in turn affect child outcomes. In support of economic theory, their study finds that hardship affects parental investment (purchasing cognitively stimulating materials, activities outside the household, extracurricular activities and parental involvement in school). They also find that material hardship and income together better explain the effect on child behavior than income alone.

\section{Financial Literacy}

Financial literacy includes knowledge, skills and attitudes related to personal financial management (OECD). Higher financial literacy might lead toward optimal financial decisions, improved financial wellbeing and household welfare. Financial literacy is also imperative for financial market stability, as substandard consumer financial decisions can pave the way for financial turmoil and defaults. Thus, financial literacy coupled with the understanding of state of the art digital financial services could enhance effective financial inclusion. Despite enormous importance, worldwide financial literacy estimates are disappointing. Financial literacy scores are low even in countries with well-developed financial markets. In addition, gender gap in financial literacy is also huge around the world. Where, men tend to be more financial savvy then women. According to a recent survey of S\&P, only $37 \%$ of adults around the world are financial literate. Further disaggregation shows that nearly $35 \%$ of males and $30 \%$ of females worldwide are found to be financially knowledgeable. Besides these survey results, a large body of empirical research report lower levels of financial literacy in the world.

Although the concept has been defined in various contexts in the literature, the definitions however differ in relation to what the definition seeks to achieve. This implies that there is no specific definition for financial literacy or there is few generally-accepted definitions and conceptual framework of personal finance. According to (Noctor, Stoney, and Stradling; 1992), financial literacy is the ability to make sound decisions regarding the use and management of money. Thus, effective decisions taken in relation to the use and control of money (Schagen and Lines 1996).Defining the concept in this context suggests that the definitions narrowed as emphasis is placed on management of money. 


\section{Socio-Economic Status}

The SES is a construct that is often applied to describe the position of an individual within a society that is characterized by social inequality (Duncan 1961; Geissler 1994). Social inequality exists if a social position is linked to social advantages or disadvantages that are caused by income, assets, power, social prestige as well as education and knowledge (Bolte and Hradil 1988; Borgers and Steinkamp 1994). Advantages and disadvantages that are caused by social position are shown not only by material goods and the resultant living conditions but also by an individual's attitudes, value systems and behavior (Hradil and Schiener 2001). There is neither consensus on a definition of neither socio-economic status nor a widely accepted socio-economic status measurement tool (Barkley 2008; Oakes and Rossi 2003). The main dimensions used to describe social inequality are education, occupation, and income (Adler and Ostrove 1999; Deaton 1999; Mackenbach et al. 2008; Oakes and Rossi 2003; Richter and Hurrelmann 2009).

These three dimensions are widely used to define the socio-economic status, which is very common in so-cial sciences and social epidemiology (Adler and Ostrove 1999; Braveman et al. 2005). Altogether, SES is a multidimensional construct that comprises diverse socioeconomic factors (cf. Abramson et al. 1982; Braveman et al. 2005; Winkler and Stolzenberg 1999). Scheuch (1970), who develops an indicator to describe social prestige and social stratification, divides prestige into three categories, namely economic situation, occupational status, and the cultural level. Based on this categorization social stratification is measured using three central indicators. The economic situation is represented by in-come, the occupational status by the social prestige of a profession, and education as the cultural level. Altogether the term socio-economic status considers actual re-sources as well as dimensions that are related to prestige. Thus SES describes simultaneously the absolute situation of an individual and the relative position within the society (Krieger et al. 1997). Although the three dimensions of socio-economic status (income, education, and occupation) are only moderately correlated with one another, they are often used inter-changeably (Ostrove and Adler 1998; Winkleby et al. 1992). Interestingly, the occupational status category is used very often as an SES category in Europe. In contrast, studies from the US more often use the dimensions of income and educational status to describe socio-economic status (Braveman et al. 2005).

\section{Health behavior}

Concerning poverty dynamics and health, there are only a small number of longitudinal studies available in the international literature. Studies examining poverty dynamics and health behavior are even rarer. Although numerous poverty measurements exist the majority of studies on poverty dynamics and health outcomes use the one-dimensional measurement of income poverty. Consequently the application of multidimensional poverty measurements is not only widespread in the realm of poverty research but also in the area of health economics and epidemiology. Thus, to the best of the author's knowledge there is a lack of research on dynamics of multidimensional poverty with regard to health behavior. This criticism is also applicable on dynamic socio-economic status including income, education and occupation to explain health behavior. As already explained in section socio-economic status is seldom used at a dynamic level It can be assumed that particularly the dimensions of education as well as 
of occupational status do not significantly change over time so that this aspect may be neglected.

Solely, the socio-economic status dimension of income is considered in dynamic analyses on health and health behavior. As mentioned at the beginning of this section, the majority of research on poverty or SES and health is based on cross-sectional data, while only few studies use longitudinal data (Benzeval and Judge 2001; McDonough and Berglund 2003). This is also valid for health behavior.

Against this background, Benzeval and Judge (2001) argued that consideration of the time factor is important for analyzing the direction of causation, but also for including information on an individual's life-course experience and for examining poverty-induced consequences for health. The authors show in a review that there are only a few studies that investigate the dynamic relationship of income and health for 1982-1997. The review shows that income is significantly related to health outcomes. Furthermore, permanent income is more relevant for health than short-term income. With regard to income changes, an individual's health is more likely to be negatively affected if income decreases over time in comparison with stable or increasing income. Additionally, Benzeval and Judge conduct dynamic analyses using data of the British Household Panel Survey (BHPS) from 1991 to 1996/97 which supports the general findings their review. McDonough and Berglund (2003) observe that increasing incomes are better for self-rated health than falling incomes. Meanwhile, current prosperous economic circumstances do not compensate the negative health effects of earlier poverty experiences.

Additionally, longer and more numerous poverty spells leads to poor health and increasing mortality (Lynch et al. 1997). Generally, the income level is more important than the income changes for health outcomes. Finally, persistent poverty is more harmful for health than occasional episodes. Nevertheless, the studies presented by Benzeval and Judge (2001) as well their own analyses concentrate mainly on health but not on health behavior. Only a few studies use single dimensions of health behavior as confounding variables (Smith and Zick 1994; Lynch et al. 1997b). Furthermore, McDonough and Berglund (2003) underline the importance to examine poverty dynamic and health not only on two or three observation points because results are less meaningful. Although income-based poverty measurements are generally used to describe poverty dynamics, McDonough et al. (2005) emphasize the importance to take further social characteristics like education into consideration. As initially mentioned, research on health behavior and poverty dynamics is seldom studied.

Lynch et al. (1997b) investigate health behavior, namely alcohol consumption, smoking, and physical activity with regard to income poverty spells in 1965, 1974 and 1983. Additionally, the risk factor of BMI was included. The authors report that the highest rates of smoking are observable for individuals who are never or only once affected by poverty. However, individuals who are poor in all three survey periods show much lower rates of physical activity. In contrast, the highest alcohol consumption is observable for those who are never affected by poverty. Nevertheless, it has to be critically noted that these dimensions of health behavior are not the focus of Lynch et al.'s study. They are used rather as covariate6 in the multivariate model examining the impact of economic hardship on physical, psycho-logical, and cognitive functioning. 


\section{Vicious Cycle of Poverty}

The vicious cycle of poverty states that the poor man is poor because he is poor or a country is underdeveloped because it is underdeveloped. The vicious cycle of poverty is a kind of curse which is feared by individuals and countries because it is said that an individual/country is poor because it is poor. The theory states that there are circular relationships known as the "vicious cycle of poverty" that tend to perpetuate the low level of development in less developed countries (LDCs). The trajectory is that poverty is caused by low income.

Low income engenders low savings and this in turn leads to low investment. The latter provokes low productivity and the cycle continues. According to Jhingan (2003), the basic vicious cycle stems from the facts that in LDCs total productivity is low due to deficiency of capital, market perfections, economic backwardness and underdevelopment. Jhingan stressed that vicious cycle operates both on the demand side and supply side. On the demand side of the vicious cycle, the low level of real income leads to a low level of demand which in turn leads to a low rate of investment and hence back to deficiency of capital, low productivity and low income.

On the supply side, low productivity is reflected in low real income. The low level of savings leads to low investment and to deficiency of capital. The deficiency of capital in turn leads to a low level of productivity and back to a low income. Accordingly, this theory views poverty as being self-perpetuating.

\section{Power Theory of Poverty}

The power theory of poverty is similar to the Maxists theory of poverty. This theory sees power in terms of who controls what and how in the political and economic structures of the system. In this context, the structure of political and economic power in the society is the determinant of the extent of poverty among the populace. This is basically the Maxian theory of historical materialism. According to this theory, the system of poverty determines the basic division of the society into two classes: they have and the have-nots (the property owners and the nonproperty owners). This view constitutes the fundamental nature of government, religion and culture in any given society. This theory further stated that the society has been dominated by the ruling class owners of properties who exploit the non-property owners, made possible by their ownership of the means of production.

According to the proponents of this theory, the individual's position in the society depends on whether he owns the means of production or work for someone else. They held religion responsible for sustaining this power structure between the rich and the poor by denying the poor of any initiative to fight to improve their condition which prevails and subject them to poverty Nyong (1995). Thus, an effective poverty reduction programme should have exploitative property that could be addressed and dislodged.

\section{Empirical Review}

Khasru and Jalil (2004) empirically investigated the Kuznets hypothesis using data for 24 countries. They used the fixed effect estimation technique to estimate their panel data model. 
In general, they found an un-inverted ' $U$ ' pattern. Though the second part of the hypothesis applies to most countries, they found that it is not applicable to developing countries like Ecuador, Cyprus, Egypt, Turkey and Chile and for newly industrialised countries like Singapore. Whereas the role economic growth plays in reducing poverty levels is extensively acknowledged, the same cannot be drawn for the role economic growth plays in reducing income inequality. There are contrasting views on the relationship between economic growth and income inequality.

Psacharopoulos et al. (1995) showed that economic growth is negatively related to income inequality. Other studies such as Ravallion and Chen (1997) found no evidence that increases in aggregate incomes led to significant reduction in income inequality among developing countries. We should however stress that both studies used scatter points that relate changes in economic growth to changes in income inequality.

Schultz (1998) investigated the economic growth-income inequality relationship but found no significant relationship. With the distribution of income becoming increasingly important to economic development, a number of studies have investigated the economic growth and poverty relationship taking into account the role income inequality plays in that relationship. Tridico (2010) analyzed the effect of economic growth on poverty and income inequality in 50 emerging and transitional economies (ETEs) between 1995 and 2006. He defined economic development as a broader process of economic growth that includes institutional changes and human development. His results suggested that economic growth had no positive impact on poverty levels. Though the estimated average growth among these countries during the period is 4.7 percent, he explained that because economic growth was not accompanied by other components of development, poverty levels were not significantly affected. He also investigated the impact of economic growth on income inequality and found that economic growth worsened income inequality during the period. According to him, lower levels of education and public Expendeture may have led to high income inequality. He therefore concluded that income inequality will increase with economic growth unless educational standards improve and governments promote good institutional quality as well as develop strategies to promote human development.

Adam (2004) used data on 60 developing countries to analyze the relationship between economic growth and poverty. He argued that while economic growth leads to reductions in poverty among developing countries, the magnitude of the effect depends more on how economic growth is defined. He defined two measures of economic growth; the survey mean income and changes in GDP per-capita. He found that economic growth leads to poverty reduction irrespective of how growth is defined. However, poverty is reduced more when mean income is used than when GDP per-capita is used.

Fanta and Upadhyay (2009) used data on 16 African countries to estimate the effect of economic growth on poverty levels. They argued that although growth is fundamental to reducing poverty levels in Africa, the growth elasticity of poverty is different among countries. Their results suggested that economic growth tends to reduce poverty in Africa. Attaining high levels of economic development allows countries to improve their standard of living. They therefore recommended policies that aim at economic development and bringing down income 
inequality in Africa. Growth elasticity of poverty is defined as the percentage change in poverty resulting from a percentage change in economic growth.

Stevans and Sessions (2008) examined the impact of economic growth on poverty levels in the United States from 1959 to 1999 . They used an error-correction model to estimate a dynamic long-term relationship between poverty and economic growth. They found that increase in economic growth is significantly related to poverty reduction for all families in the United States. According to them, growth had a more pronounced impact on poverty levels during the expansionary periods of the 1960's, 1970's, 1980's and 1990's. This is because workers, particularly the poor, found employment opportunities during periods of high and sustained economic growth as opposed to economic slowdowns.

Sadoulet and Janvry (2000) exceptionally higher levels of income inequality than other regions at similar levels of average income per-capita. They investigated the effects of economic growth on rural and urban poverty levels in Latin America from 1970-1994 taking into account the differences in income distributions. They found that, growth significantly reduced poverty levels when there were low levels of income inequality. There is therefore a high cost of income inequality.

Lee and Perera (2013) investigated the contribution of economic growth and institutional qualities to the reduction in poverty in Asia from 1985 to 2009. They argued that, there are many factors behind the persistent poverty problems in developing countries and that economic growth alone cannot account for all the changes in poverty levels. Some of the factors include government stability and rule of law, corruption, and democratic accountability. They found that economic growth significantly reduced poverty levels in the South and East Asia region. Economic growth leaves the income distribution unchanged and therefore results in a higher reduction in poverty levels. On the institutional qualities, they found a negative relationship between government stability, rule of law, and poverty. Thus, improvements in institutional qualities led to a reduction in poverty levels over the years. However, a reduction in corruption, improvements in democratic accountability and bureaucracy have not contributed to reducing poverty and income inequality. This result is interesting since corruption in particular is seen as detrimental to economic development. Moderate rates of corruption may not be harmful to growth initially but in the long run, they argued that corruption will have an adverse effect on economic development and may worsen poverty levels even further. Therefore governments in Asia should adopt policies to mitigate corruption and promote quality institutions. Mullainathan and Shafir (2010) demonstrated greater depleting effects on math performance by New Jersey mall shoppers of an expensive hypothetical car repair decision than an inexpensive one, with the greatest effects on less wealthy shoppers. Poverty may have many effects on behavior, many of which could be unrelated to behavioral control. Deaton(1990) observes that allowing heterogeneity in discount rates in a theory of consumption under borrowing constraints "divides the population into two groups, one of which lives a little better than hand to mouth but never has more than enough to meet emergencies, while the other, as a group, saves and steadily accumulates assets. For consumers whose impatience exceeds the rate of return to investing, remaining poor is optimal.

Lawrance(1991) proposed different rates of time preference as one possible explanation for observed heterogeneity in savings behavior across socioeconomic classes estimating that the 
poor are less patient from the fact that their consumption grows less quickly. While time preference influences wealth directly through savings, it could also have indirect effects by shaping investments in education (Card, 1995) or health (Fuchs, 1982). The behavioral economics of time inconsistency has further focused on implications of heterogeneity in discounting, present bias, and sophistication (O’Donoghue and Rabin, 1999).

Ashraf, Karlan, and Yin (2006) argued that, absent certain institutions, hyperbolic discounters are especially unlikely to save. Yet, recent findings and theories in both psychology and economics suggest revisiting Fisher's suggestion. Indeed, poor people like rich people do often act impatiently.

\section{Literature Gap}

Tridico (2010) analyzed the effect of economic growth on poverty and income inequality in 50 emerging and transitional economies (ETEs) between 1995 and 2006. Adam (2004) used data on 60 developing countries to analyze the relationship between economic growth and poverty. Fanta and Upadhyay (2009) used data on 16 African countries to estimate the effect of economic growth on poverty levels. The empirical literature reviewed in this study is foreign studies and does not capture the effect of immune financial deficiency syndrome and the behavior of low income earners. This study will focus on Nigeria with the objective of examining the relationship between immune financial deficiency syndrome and the behavior of low income earners in the rural communities of Rivers State.

\section{METHODOLOGY}

The researcher used in this study is the cross sectional research design, which is selected because it would ably facilitate the collection of data from the different strata of respondents namely accounting officer, accountants, auditors, accounts assistants and department heads in the deposit money banks. This helped the researcher to get the individual characteristics of the variables under study. The study population consists of all low income earners in rural communities of the 23 local governments of Rivers State. A sample frame of 10 local governments with 10 representatives drawn from the 23 local governments in the State, the Local governments are Ahoada West, Ahoada East, Eleme, Gokana, Kanah, Etche , Abua/Odua, Omuma, Oyigbo and Obio/Akpor local governments. From the above, the sample size of the study is 100 respondents selected using judgmental sampling techniques.

In this study, the measurement of variables was done individually. This study has one independent variable and one dependent variable. The independent variable has five major constructs that include four socio-cultural, behavior, mental, emotional and health wellbeing, while the dependent variable has constructs which mainly summaries financial immune deficiency syndrome.

\section{Data Collection Sources}

The study uses primary data as original data that will be collected for the first time and it will be retained by form of questionnaires which will be sent out to a certain number of low income earners as well preferably via Internet research assistant. The study will use closed questions 
that is will be utilized where it is possible to restrict responses to predetermined answers or where alternatives are few. On the other hand, open questions will be used where details were needed and where there were many alternative choices.

\section{Validity}

The validity of an instrument is defined as the ability to an instrument to measure what it is intended to measure. In this study, the validity of the instruments will be established by a panel of experts through an assessment of selected items in the instruments that ensured that the instruments are measuring to the expectations. After identifying the vague and ambiguous questions, corrections will be made and final instruments were prepared. Also Content Validity Index (CVI) will be computed from responses of Two (2) Experts which are expected to be between the coefficient of 0.9205 and 0.8864 , respectively and this indicates that the questionnaire is relevant.

\section{Reliability}

The reliability of an instrument is defined as the consistence of the instrument in picking the needed information. Reliability (Internal consistency and stability) of the instruments will be tested using Cronbach's Alpha ( $\alpha$ ) coefficients (Cronbach, 1946). The researcher will test the inter-item consistency reliability to ensure that there is the consistency of respondents 'answers to all items in the measure.

\section{Data Processing, Analysis and Presentation}

The statistical techniques employed in analyzing data collected in this study are:

- Tables

Tables effectively order and summarize the quantitative data. They are used to arrange facts and figures in columns and rows. These facts and figures can be systematically examined. (Ojo, 2005).

\section{- Percentages}

These are used in translating frequency counts into percentage. These percentages were used to show the distribution of respondents according to their responses (Ojo, 2005)

\section{- Correlation Analysis}

It is used as a measure of the strength of linear dependence between two variables. According to Ojo (2005) correlation is used to find out if there is any relationship between two variables. While doing this, a variable is correlation to another variable. Spearman rank correlation coefficient with the aid of the Statistical Package for Social Sciences, (SPSS) Version 20.0. The correlation coefficient ranges from -1 to 1 . A value of 1 implies that a linear equation describes the relationship between $\mathrm{X}$ and $\mathrm{Y}$ perfectly, with all factors affecting $\mathrm{Y}$ held constant for which $\mathrm{Y}$ increases as $\mathrm{X}$ increases. A value of -1 implies $\mathrm{Y}$ decreases as $\mathrm{X}$ increases. A value of 0 implies that there is no linear correlation between the variables.

\section{ANALYSIS AND DISCUSSION OF FINDINGS}

The structured questionnaire was adopted as the primary data instrument and a total of 100 respondents were targeted for inclusion in the study, however, as a result of various unexpected 
in contingencies, only 89 questionnaire copies were successfully retrieved and utilized in the study. This reduction and shortage is attributed to the absence and failure of some of the respondents to complete their copies of the questionnaire. Furthermore, after retrieval, questionnaire copies were treated for errors and missing values and results revealed a $2 \%$ error rate due to missing values which were thereafter treated through the allocation of mode values to the blank sections.

The data generated was categorized into sections based on the nature of the variable of interest. The sections include: the demographic data, the data on the variables of the study and also the data for the moderating variable. Each data is analyzed accordingly with the results presented herein

\section{Demographic Analyses}

The demographic section of this study presents the data on the distribution of the respondents according to characteristics such as gender, qualification, age and position or level in the organization. The data at this level is considered as discrete and thus analysis is based on the description of distribution according to frequencies and percentages. The bar chart and contingency tables are adopted in the illustration of the data.

Table 1: Gender of the respondents of the study

\begin{tabular}{llllll}
\hline & & Frequency & Percent & Valid Percent & Cumulative Percent \\
\hline Valid & Male & 62 & 69.7 & 69.7 & 69.7 \\
& Female & 27 & 30.3 & 30.3 & 100.0 \\
& Total & 89 & 100.0 & 100.0 & \\
\hline
\end{tabular}

Source: Survey result 2019

Figure 4.1: Gender analysis for the respondents of the study

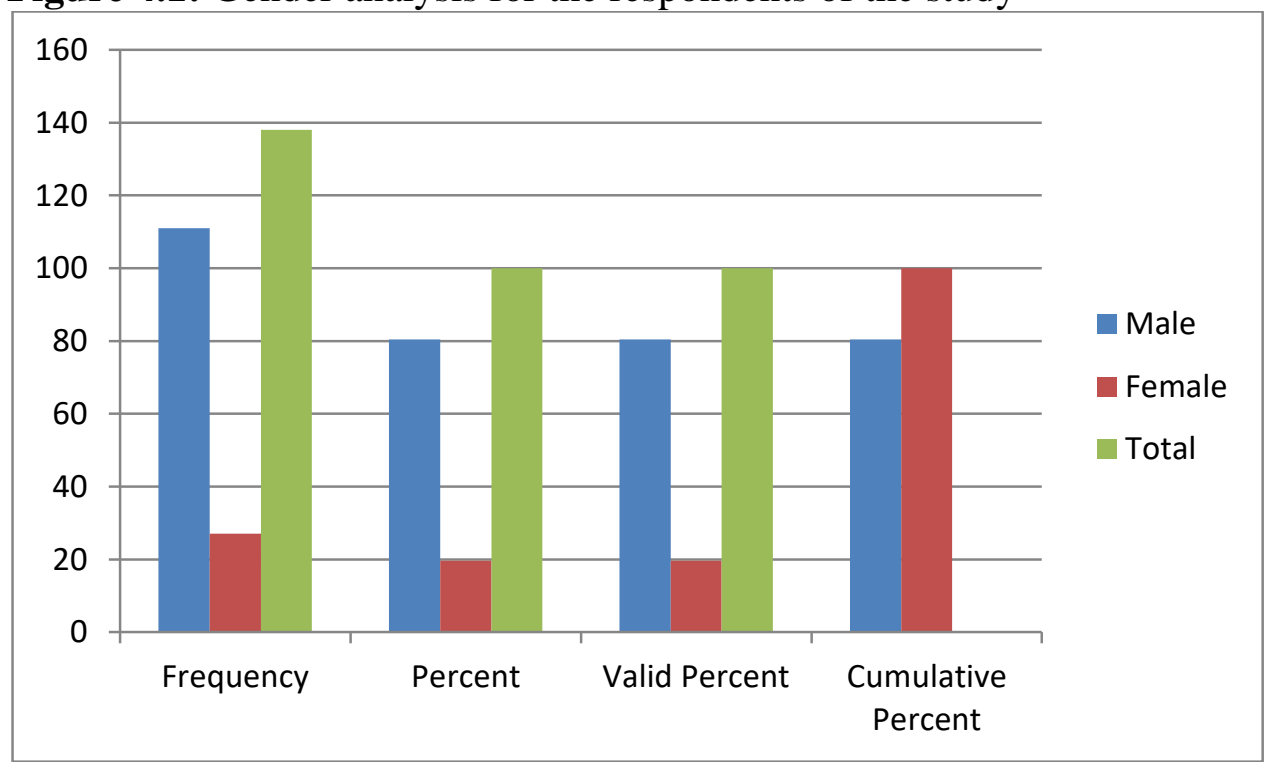


Print ISSN: 2053-5821(Print), Online ISSN: 2053-583X (Online)

The results of the analysis (table 4.1 and figure 4.1) illustrates that for the gender distribution of the study, majority of the respondents who participated in the study are male with a relative low frequency for the female category.

Table 2: Qualification of the respondents of the study

\begin{tabular}{|c|c|c|c|c|c|}
\hline & & Frequency & Percent & Valid Percent & $\begin{array}{l}\text { Cumulative } \\
\text { Percent }\end{array}$ \\
\hline \multirow[t]{5}{*}{ Valid } & Diploma/NCE Cert. & 9 & 10.1 & 10.1 & 10.1 \\
\hline & First Degree/BSc/BTech & 31 & 34.8 & 34.8 & 44.9 \\
\hline & $\begin{array}{l}\text { Post Graduate } \\
\text { Degree/MBA/MSc }\end{array}$ & 27 & 30.3 & 30.3 & 75.2 \\
\hline & $\begin{array}{l}\text { Professional } \\
\text { Cert/Microsoft/ICAN }\end{array}$ & 22 & 24.7 & 24.7 & 100.0 \\
\hline & Total & 89 & 100.0 & 100.0 & \\
\hline
\end{tabular}

Source: Survey result 2019

Figure 4.2: Qualification analysis for the respondents of the study

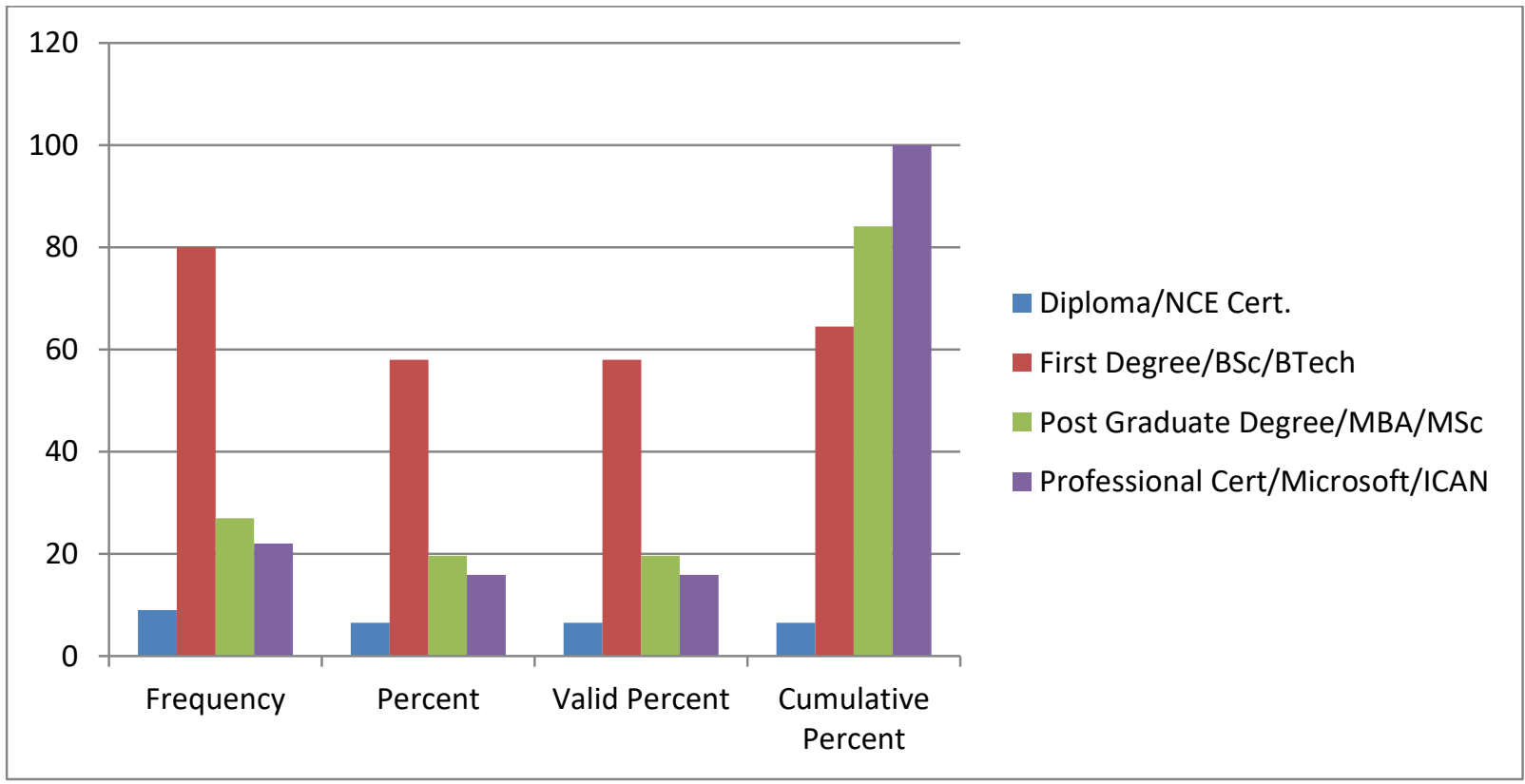

The results for the analysis on respondents educational qualification (figure 4.2 and table 4.2) shows that a higher percentage of the respondents have only acquired first degree certifications $(58 \%)$, with the next high frequency percentage for respondents in the post graduate degree $(20 \%)$, then the professional certifications (22\%) and finally the diploma certifications category $(6 \%)$.

\section{Univariate Analyses}

The univariate section is concerned with the presentation of the data for the variables of the study. The data presented herein is continuous and so is assessed using the mean and standard deviation in the assessment of its central tendencies and dispersion. Given the positive statements adopted in the measurement of each variable and the scaling method which ranks 
from $1=$ for strongly disagree to $5=$ strongly agree, a mean score of $x>2.5$ with a relative standard deviation of $\mathrm{s}<2.0$ is adopted as substantial evidence of support or agreement to the indicator.

Table 3: $\quad$ Research Question One

\begin{tabular}{llll}
\hline S/N & Response & Frequency & Percentage \\
\hline 1 & Strongly Agree & 45 & 50.6 \\
2 & Agree & 38 & 42.7 \\
3 & Undecided & 1 & 1.12 \\
4 & Disagree & 4 & 4.5 \\
5 & Strongly Disagree & 1 & 1.12 \\
& Total & 89 & 100 \\
\hline
\end{tabular}

Source: Survey result 2019

The result of respondents base on question one proved that 45 respondent out the 89 strongly this represent 50.6 percent of the total distribution, 38 respondents agree which is 42.7 percent, 1 respondent have no decision which represent 1.12 percent, 4 respondents disagree which is 4.5 percent while 1 respondent strongly disagree which is 1.12 percent, from the above we conclude that unemployment affect mental behavior of low income earners in rural communities of Rivers State.

Table 4: Descriptive Analysis of Question one

\begin{tabular}{|c|c|c|c|c|c|}
\hline Unemployment & $\mathbf{N}$ & Minimum & Maximum & Mean & $\begin{array}{l}\text { Std. } \\
\text { Deviation }\end{array}$ \\
\hline To be unemployed is problem & 89 & 1.00 & 5.00 & 4.0700 & 1.16828 \\
\hline $\begin{array}{l}\text { Unemployed person are mentally not } \\
\text { wellbeing }\end{array}$ & 89 & 1.00 & 5.00 & 4.0435 & 1.20746 \\
\hline Unemployed persons are financially deficient & 89 & 1.00 & 5.00 & 4.1014 & 1.29169 \\
\hline Unemployed person financially excluded & 89 & 1.00 & 5.00 & 4.0652 & 1.13476 \\
\hline
\end{tabular}

Source: Survey result 2019

The result for the analysis on accounting information (table 4.6) reveals that each indicator of the dimensions of the variable is observed to have high mean scores and low standard deviations. This indicates that most of the respondents believe to a considerable degree that their organizations unemployment affects mental behavior of low income earners in Rivers State. The data also reveals a low level of dispersion in terms of opinions with regards to the actual average response on the subject matter.

Table 5: $\quad$ Research Question Two

\begin{tabular}{llll}
\hline S/N & Response & Frequency & Percentage \\
\hline 1 & Strongly Agree & 51 & 57.3 \\
2 & Agree & 22 & 24.7 \\
3 & Undecided & 4 & 4.5 \\
4 & Disagree & 8 & 8.9 \\
5 & Strongly Disagree & 4 & 4.5 \\
& Total & 89 & 100 \\
\hline
\end{tabular}

Source: Survey result 2019 
The result of respondents base on question two proved that 51 respondent out the 89 strongly agree, this represent 57.3 percent of the total distribution, 22 respondents agree which is 24.7 percent, 4 respondent have no decision which represent 4.5 percent, 8 respondents disagree which is 8.9 percent while 4 respondent strongly disagree which is 4.5 percent, from the above we conclude that financial exclusion relates to emotional behavior of low income earners in rural communities of Rivers State

Table 6:Descriptive Analysis of Question two

\begin{tabular}{llllll}
\hline Financial exclusion & N & Minimum & Maximum & Mean & $\begin{array}{l}\text { Std. } \\
\text { Deviation }\end{array}$ \\
\hline $\begin{array}{l}\text { Some persons are financially excluded } \\
\begin{array}{l}\text { Exclusion from financial services have effect on } \\
\text { low income earners }\end{array}\end{array}$ & 89 & 1.00 & 5.00 & 4.1014 & .84827 \\
$\begin{array}{l}\text { Financial exclusion have effect on emotional } \\
\text { wellbeing of peoples }\end{array}$ & 89 & 1.00 & 5.00 & 3.9783 & .84116 \\
$\begin{array}{l}\text { Financial exclusion is a emotional challenge to } \\
\text { people }\end{array}$ & 89 & 1.00 & 5.00 & 4.1449 & .95559 \\
It is better for people to be financial included & 89 & 1.00 & 5.00 & 4.2029 & .92932 \\
\hline
\end{tabular}

Source: Survey result 2019

The result for the analysis on financial exclusion (table 4.8) reveals that each indicator of the dimensions of the variable is observed to have high mean scores and low standard deviations. This indicates that most of the respondents believe to a considerable degree that financial exclusion relates to emotional behavior of low income earners in rural communities of Rivers State. The data also reveals a low level of dispersion in terms of opinions with regards to the actual average response on the subject matter.

Table 7: $\quad$ Research Question three

\begin{tabular}{llll}
\hline S/N & Response & Frequency & Percentage \\
\hline 1 & Strongly Agree & 19 & 21.3 \\
2 & Agree & 59 & 66.3 \\
3 & Undecided & 3 & 3.4 \\
4 & Disagree & 5 & 5.6 \\
5 & Strongly Disagree & 3 & 3.4 \\
& Total & 89 & 100 \\
\hline
\end{tabular}

Source: Survey result 2019

The result of respondents base on question three proved that 19 respondents out the 89 strongly agree this represent 21.3 percent of the total distribution, 59 respondents agree which is 66.3 percent, 3 respondents have no decision which represent 3.4 percent, 5respondents disagree which is 5.6 percent while 3 respondents strongly disagree which is 3.4 percent, from the above we conclude that spiritualism affect health wellbeing of low income earners in rural communities of Rivers State. 
Print ISSN: 2053-5821(Print), Online ISSN: 2053-583X (Online)

Table 8: Descriptive Analysis of Question three

\begin{tabular}{|c|c|c|c|c|c|}
\hline Spiritualism & $\mathbf{N}$ & Minimum & Maximum & Mean & $\begin{array}{l}\text { Std. } \\
\text { Deviation }\end{array}$ \\
\hline $\begin{array}{l}\text { Poor financial motivation lead to inability to } \\
\text { generate fund }\end{array}$ & 89 & 1.00 & 5.00 & 4.6543 & 1.45323 \\
\hline One must be spiritually motivated financially & 89 & 1.00 & 5.00 & 4.8905 & 1.32176 \\
\hline Lack financial spiritualism demotivates people & 89 & 1.00 & 5.00 & 4.3521 & 1.00865 \\
\hline $\begin{array}{l}\text { Financial spiritualism affect socio-cultural } \\
\text { wellbeing }\end{array}$ & 89 & 1.00 & 5.00 & 4.6523 & 1.17654 \\
\hline $\begin{array}{l}\text { Lack of financial spiritualism lead to financial } \\
\text { deficiency }\end{array}$ & 89 & 1.00 & 5.00 & 4.8431 & 1.74562 \\
\hline
\end{tabular}

Source: Survey result 2019

The result for the analysis on spiritualism (table 4.6) reveals that each indicator of the dimensions of the variable is observed to have high mean scores and low standard deviations. This indicates that most of the respondents believe to a considerable degree that spiritualism affect health wellbeing of low income earners in rural communities of Rivers State. The data also reveals a low level of dispersion in terms of opinions with regards to the actual average response on the subject matter.

Table 9: $\quad$ Research Question four

\begin{tabular}{llll}
\hline S/N & Response & Frequency & Percentage \\
\hline 1 & Strongly Agree & 29 & 32.5 \\
2 & Agree & 33 & 37.1 \\
3 & Undecided & 6 & 6.7 \\
4 & Disagree & 17 & 19.1 \\
5 & Strongly Disagree & 4 & 4.5 \\
& Total & 89 & 100 \\
\hline
\end{tabular}

Source: Survey result 2019

The result of respondents base on question four proved that 29 respondent out the 89 strongly agree, this represent 32.5 percent of the total distribution, 33 respondents agree which is 37.1 percent, 6 respondents have no decision which represent 6.7 percent, 17 respondents disagree which is 19.1 percent while 4 respondent strongly disagree which is 4.5 percent, from the above we conclude that financial illiteracy affect socio-cultural behavior of low income earners in rural communities of Rivers State.

Table 10: Descriptive Analysis of Question four

\begin{tabular}{lllll}
\hline Financial literacy & $\mathbf{N}$ & Minimum & Maximum & $\begin{array}{l}\text { Std. } \\
\text { Mean }\end{array}$ \\
Deviation
\end{tabular}

Source: Survey result 2019 
The result for the analysis on financial literacy (table 4.8) reveals that each indicator of the dimensions of the variable is observed to have high mean scores and low standard deviations. This indicates that most of the respondents believe to a considerable degree that financial illiteracy affect socio-cultural behavior of low income earners in rural communities of Rivers State. The data also reveals a low level of dispersion in terms of opinions with regards to the actual average response on the subject matter.

\section{Test of Hypotheses}

Ho1: There is no significant relationship between unemployment and mental behavior of low income earners in rural communities of Rivers State

Correlations

\begin{tabular}{llll}
\hline \hline & & UE & MB \\
\hline UE & Pearson Correlation & 1 & $.689 * *$ \\
& Sig. (2-tailed) & & .000 \\
& $\mathrm{~N}$ & 89 & 89 \\
\hline MB & Pearson Correlation & $.689 * *$ & 1 \\
& Sig. (2-tailed) & .000 & \\
& $\mathrm{~N}$ & 89 & 89 \\
\hline \hline
\end{tabular}

** Correlation is significant at the 0.01 level (2-tailed)

The results of the analysis reveal that unemployment determines behavior of low income earners in the rural communities. The analysis reveals a significant relationship between unemployment and mental behavior as the correlation coefficient of 0.689 where the $\mathrm{P}$ is significant at a 0.000 coefficient. The null hypothesis is rejected in this case.

Ho2: $_{\text {: }}$ There is no significant relationship between financial exclusion and to emotional behavior of low income earners in rural communities of Rivers State.

\section{Correlations}

\begin{tabular}{llll}
\hline \hline & & FEX & MB \\
\hline FEX & Pearson Correlation & 1 & $.785^{* *}$ \\
& Sig. (2-tailed) & & .000 \\
& $\mathrm{~N}$ & 89 & 89 \\
\hline EB & Pearson Correlation & $.785^{* *}$ & 1 \\
& Sig. (2-tailed) & .000 & \\
& $\mathrm{~N}$ & 89 & 89 \\
\hline \hline
\end{tabular}

** Correlation is significant at the 0.01 level (2-tailed)

The results of the analysis reveal that financial exclusion determine emotional behavior of low income earners in the rural communities. The analysis reveals a significant relationship between unemployment and mental behavior as the correlation coefficient of 0.645 where the $\mathrm{P}$ is significant at a 0.000 coefficient. The null hypothesis is rejected in this case.

H03: There is no significant relationship between spiritualism and health wellbeing of low income earners in rural communities of Rivers State. 


\section{Correlations}

\begin{tabular}{llll}
\hline \hline & & SP & HWB \\
\hline SP & Pearson Correlation & 1 & $.770^{* *}$ \\
& Sig. (2-tailed) & & .000 \\
& $\mathrm{~N}$ & 89 & 89 \\
\hline HWB & Pearson Correlation & $.770^{* *}$ & 1 \\
& Sig. (2-tailed) & .000 & \\
& $\mathrm{~N}$ & 89 & 89 \\
\hline \hline
\end{tabular}

$* *$ Correlation is significant at the 0.01 level (2-tailed)

The results of the analysis reveal that spiritualism significantly determines health wellbeing of low income earners in rural communities of Rivers State. The analysis reveals a significant relationship between spiritualism and health wellbeing determination as the correlation coefficient of 0.770 where the $\mathrm{P}$ is significant at a 0.000 coefficient. The null hypothesis is rejected in this case.

Ho4: There is no significant relationship between financial illiteracy and socio-cultural behavior of low income earners in rural communities of Rivers State.

\section{Correlations}

\begin{tabular}{llll}
\hline \hline & & FL & SCB \\
\hline FL & Pearson Correlation & 1 & $.804^{* *}$ \\
& Sig. (2-tailed) & & .000 \\
& $\mathrm{~N}$ & 89 & 89 \\
\hline SCB & Pearson Correlation & $.804^{* *}$ & 1 \\
& Sig. (2-tailed) & .000 & \\
& $\mathrm{~N}$ & 89 & 89 \\
\hline \hline
\end{tabular}

** Correlation is significant at the 0.01 level (2-tailed)

The result of the analysis reveals that financial literacy significantly determines socio-cultural behavior of low income earners in rural communities of Rivers State. The analysis reveals a significant relationship between financial literacy and socio cultural behavior of low income earners in rural communities of Rivers State at a correlation coefficient of 0.804 where the $P$ is significant at a 0.000 coefficient. The null hypothesis is rejected in this case.

\section{DISCUSSION OF FINDINGS}

The social status scale by Winkler and Stolzenberg (1999) includes, in addition to household income, the level of education and occupational qualification as well as the highest occupational status within the household (Winkler and Stolzenberg 1999). SES by Winkler and Stolzenberg is based on Scheuch's index (Scheuch 1970). Studies in the area of social epidemiology in Germany apply this indicator (Lampert and Kroll 2009). Many negative behaviors are more prevalent among socially disadvantaged groups. A number of specific mechanisms have been proposed to explain this. First, some healthy behaviours are expensive, for example a healthy diet has been shown to be more expensive than an unhealthy one, joining 
a gym or taking part in extra school sporting clubs can be costly. Second, people use some unhealthy behaviours such as smoking or drinking alcohol as a way of coping with difficult financial situations (Bannered, 2000). A linked argument is that the difficulties of coping with life on low incomes inclines people to discount the future more heavily, meaning people are less concerned with the long-term health-damaging effects of behaviors that bring them current pleasure or stress relief.

The research questions found that financial immune deficiency syndrome significantly affect behavior of low income earners. The research questions and hypotheses found that unemployment have positive and significant relationship with emotional behavior. Research question two established a valid positive and significant relationship between financial exclusion and emotional behavior of low income earners in Rivers State. The findings in this study show that the independent variables have positive and significant relationship with the dependent variable. This finding confirms the expectation of the results and validates the objective of reducing poverty in the society.

\section{CONCLUSION}

The study was motivated to investigate the relationship between financial deficiency syndromes on the behavior of low income earners in Rivers State. From the findings, we make the following conclusions:

Unemployment has positive and significant effect on mental behavior of low income earners in Rivers State.

Financial exclusion has positive and significant effect on mental behavior of low income earners in Rivers State.

Spiritualism has positive and significant effect on mental behavior of low income earners in Rivers State.

Financial illiteracy has positive and significant effect on mental behavior of low income earners in Rivers State.

\section{Recommendations}

The study makes the following recommendations

1. Government should formulate policies that will reduce unemployment in rural communities. There is also needs to increase public awareness on financial inclusion in the rural communities.

2. Efforts should be advanced by the government to reduce financial exclusion in the rural communities of rivers state.

3. Regulatory authorities should ensure equitable distribution of financial institutions and financial servicing to the rural communities in Rivers State.

\section{REFERENCES}

Adams, R. H. (2004). Economic growth, inequality and poverty: estimating the growth elasticity of poverty.Journal of World Development, 32(12), 11-27.

Ali, A.A. and Thorbecke, E. (2000). The State and path of poverty in Sub-Saharan Africa: some preliminary results, Journal of African Economies, 9, 9-40.

Alonso-Borrego, C. and Arellano, M. (1996). Symmetrically normalized instrumental 
Arellano, M. and Bond, S. (1991). Some tests of specification for panel data: Monte Carlo evidence and application to employment equations. The Review of Economic Studies, 58, 277-297.

Arellano, M. and Bover, O. (1995). Another look at the instrumental variables estimation of the error component models, Journal of Econometrics, 68, 29-51.

Baltagi, B.H. (1995). Econometric Analysis of panel data. New York: Wiley.

Beck, N. and Katz, J.N. (1995). What to do (and not to do) with time-series cross- section Data, The American Political Science Review, vol.89, iss.3 (Sep., 1995), 634-647.

Beck, N. and Katz, J.N. (1996).Nuisance vs. Substance: specifying and estimating time-seriescross-section models", Political Analysis 6: 1-36.

Beck, N. and Katz, J.N. (2009).Modeling dynamics in time-series-cross-section political economy data, Social Science Working Paper 1304.

Blundell, R. and Bond, S. (1998). Initial conditions and moment restrictions in Dynamic Panel Data Models", Journal of Econometrics 87:115-143. Available at

Bond, S. (2002). Dynamic Panel Data Models: A Guide to Micro Data Method and

Chemli, L. and Smida, M. (2013). Interaction between Poverty, Growth and Inequality during Crisis: A Panel Data Study, International Journal of Economics and Finance, vol. 5. No. 5.

Chen, S. and Ravallion, M. (2008). The World Bank, Policy Research Working Paper Series: 4703.

Chen, S. and Ravallion, M. (2010). The Developing World is Poorer than we Thought, but no less Successful in the Fight Against Poverty. The Quality Journal of Economics, November 2010, v.125, iss.4, pp.1577-1625.

Cypher, J and Dietz, J (2004). The Process of Economic Development, 2nd edition. Routledge, London and New York.

Deininger, K. and Squire, L. (1998), New ways of Looking at Old Issues: Inequality and Growth, Journal of Development Economics, 57(2), 259-287.

Dhongde, S and Miao, X. (2013). Cross Country Convergence in Income Inequality Society for the Study of Economic Inequality, Working Papers Series 2013.

Dollar, D. and Kraay, A. (2002). Growth is Good for the Poor, Journal of Economic Growth, vol.7 No.3 (Sep., 2002), pp. 195-225.

Dollar, D. and Kraay, A. (2004). Trade, Growth, and Poverty, The Economic Journal, 114 (February), F22-F49.

Dollar, D., Tatjana, K. and Kraay, A. (2013). Growth still is Good for the Poor, the World Bank Policy Research Working Paper Series (PRWP): 6568, 2013.

Easterly, W. (2000). The Effect of IMF and World Bank Programs on Poverty, World Bank, mimeo, Washington DC: World Bank.

Fanta, F. and Upadhyay, M. P. (2009). Poverty Reduction, Economic Growth and Inequality in Africa, Applied Economics Letters, 2009, 16, 1791-1794.

Farah, M. J., Betancourt, L., Shera, D. M., Savage, J. H., Giannetta, J. M., Brodsky, N. L., ... Hurt, H. (2008). Environmental stimulation, parental nurturance and cognitive development in humans.Developmental Science, 11, 793-801. doi: 10.1111/j.14677687.2008.00688.x

Field, G. (1980). Poverty, Inequality and Development, Cambridge University Press, 1980, pp. 46-56.

Fosu, K. A. (2008). Inequality and the Growth-Poverty Nexus: Specification Empirics Using Africa Data, Applied Economics Letters, 2008, 15, 563-566. 
International Journal of Small Business and Entrepreneurship Research

Vol.8, No.1, pp.14-38, January 2020

Published by ECRTD-UK

Print ISSN: 2053-5821(Print), Online ISSN: 2053-583X (Online)

Fosu, K. A. (2010a). Does Inequality Constraint Poverty Reduction Programs? Evidence from Africa, Journal of Policy Modelling32 (2010) 818-827.

Fosu, K. A. (2010b). Growth, Inequality and Poverty Reduction in Developing Countries: Recent Global Evidence, Centre for the Study of African Economies (CSAE) WPS/2011-07.

Fosu, K. A. (2010c). Inequality, Income and Poverty: Comparative Global Evidence, Social Science Quarterly, vol. 91, No. 5, December 2010.

GarcíaColl, C. T., \&Szalacha, L. A. (2004).The multiple contexts of middle childhood.Future of Children, 14, 80-97.

Green, W.H. (2008). Econometric Analysis, 6th edition, Pearson.

Guarini, T. E., Marks, A. K., Patton, F., \& Garcia Coll, C. T. (2011). The immigrant paradox in sexual risk behavior among Latino adolescents: Impact of immigrant generation and gender. Applied Developmental Science, 15, 201-209.

Hackman, D. A., Betancourt, L. M., Brodsky, N. L., Kobrin, L., Hurt, H., \& Farah, M. J. (2013). Selective impact of early parental responsivity on adolescent stress reactivity.PLoS ONE, 8.doi: 10.1371/journal.pone.0058250

Ijaiya, T.G. and Ijaiya, A.M. (2004). Foreign Aid and Poverty Reduction in Sub-Saharan Africa: A Cross-Country Investigation, South African Journal of Economic and Management Sciences, NS vol.7 No.3, September 2004.

Jalil, M.M. and Khasru, S.M. (2004). Revisiting Kuznets Hypothesis; An Analysis with Time Series and Panel Data, The Bangladesh Development Studies, vol. xxx, SeptemberDecember 2004, Nos. 3 \& 4.

Kiviet, J.F. (1995). On the Bias, Inconsistency and Efficiency of various Estimators in Dynamic Panel Data Models, Journal of Econometrics 68: 53-78.

Kraay, A. (2007). Aid, Growth and Poverty, Journal of Development Economics, March 2007, v.82, iss.2, 315-47.

Kuznets, S. (1955), Economic Growth and Income Inequality, American Economic Review, $45(1), 1-28$.

Mani, A., Mullainathan, S., Shafir, E., \& Zhao, J. (2013). Poverty impedes cognitive function. Science, 341, 976-980.

Masud, N. and Yontcheva, B. (2005). Does Foreign Aid Reduce Poverty? Empirical Evidence from Nongovernmental and Bilateral Aid, IMF Working Paper WP/05/100.

Nickel, S.J. (1981). Biases in Dynamic Models with Fixed Effects, Econometrica49: 14171426.

Noble, K. G., Houston, S. M., Kan, E., \& Sowell, E. R. (2012). Neural correlates of socioeconomic status in the developing human brain. Developmental Science, 15, 516527.

OECD (2011). Divided We Stand: Why Inequality Keeps Rising. http://www.oecd.org/social/soc/49170768.pdf

Pedro, O., Kathleen, B., Carlos, S. and Hiroki U. (2013) The state of the poor: where are the poor, Where is the Extreme Poverty Harder to End, and What is the Current Profile of the World's Poor? Poverty Reduction and Economic Management Network (PREM), World Bank, October 2013, No. 125.

Perera, D.L.H. and Lee, G.H.Y. (2013). Have economic growth and institutional quality contributed to poverty and inequality reduction in Asia? Journal of Asian economics, 27(2013) 71-86.

Practice. Working paper CWP09/02, Cemmap, institute for fiscal studies. 
Psacharopoulos, G. Morley, S., Fiszbein, A. Lee, H. and Wood, W. (1995). Poverty and income inequality in Latin America during the 1980s, Review of Income and Wealth, series 41, No. 3, pp. 245-64, Sep. 1995.

Racz, S. J., McMahon, R. J., \&Luthar, S. S. (2011). Risky behavior in affluent youth: Examining the co-occurrence and consequences of multiple problem behaviors. Journal of Child and Family Studies, 20, 120-128.

Ravallion, M. (1995). Growth and Poverty: Evidence for Developing Countries in the 1990s, Economics Letters, 48 (June), 411-417.

Ravallion, M. (1997). “Can High-Inequality Countries Escape Absolute Poverty”? Economics Letters 56 (1), 51-57.

Ravallion, M. (2001). Growth, Inequality and Poverty: Looking Beyond Averages, World Development, 29, 1803-1815.

Ravallion, M. (2001). Inequality Convergence, World Bank, 2011.

Ravallion, M. (2011). A comparative Perspective on Poverty Reduction in Brazil, China and India, World Bank Research Observer, February 2011, v.26, iss. 1, pp.71-104.

Ravallion, M. (2013). How Long Will it Take to Lift One Billion People out of Poverty? Policy Research Working Paper 6325, January 2013.

Ravallion, M. and Chen, S. (1996). What can new survey data tells us about recent changes in distribution and poverty? The World Bank Economic Review, 11 (1), 345-361.

Ravallion, M. and Chen, S. (2007). China's Uneven Progress against Poverty", Journal of Development Economics 82 (1): 1-42.

Roodman, D. (2009). How to Do xtabond2: An Introduction to Difference and System GMM in Stata, The Stata Journal (2009) 9, number 1, pp. 86-136.

Sadoulet, E. and De Janvry, A. (2000). Growth, Poverty and Inequality in Latin America: A Casual Analysis, 1970-94, Review of Income and Wealth, series 46, No. 3, September 2000.

Salvatore, D. (2007). Growth, International Inequalities and Poverty in a Globalizing World.Journal of Policy Modeling 29 (2007) 635-641.

Schultz, T.P. (1998). Inequality in the Distribution of Personal Income in the World: How It Is Changing and Why, Journal of Population Economics, August 1998, v. 11, iss.3, pp. 307-44

Shah, A. K., Mullainathan, S., \&Shafir, E. (2012).Some consequences of having too little.Science, 338, 682-685. doi: 10.1126/science.1222426

Smeeding, T.M. (2005). Public Policy, Economic Inequality and Poverty: The United States in Comparative Perspective, Social Science Quarterly, supplement to vol. 86.

Solt, Frederick. 2009. "Standardizing the World Income Inequality Database. Social Science Quarterly, 90(2):231\{242. SWIID Version 4.0, September 2013.

Son, H.H. (2007). Interrelationship between Growth, Inequality and Poverty: The Asian Experience, Asian Developing Review; 2007, vol. 24, no. 2, pp. 37-63.

Stevens, K.L and Sessions, D.N. (2008). The Relationship between Poverty, Economic growth, and Inequality Revisited, Journal of Income Distribution, march 2008, v.17,iss.1, pp. 5-20.

Todaro, M. And Smith, S. (2009). Economic Development, tenth -edition.

Tridico, P. (2010). Growth, Inequality and Poverty in Emerging and Transition Economies, Transition Studies Review, Feb 2010, vol. 16, iss.4, pp. 979-1001.

United Nation Development Program (1990). Human Development Report (HDIs) 2013, UN, New York. 
United Nation Development Program (2013). Millennium Development Goals (MDGs) Report 2013. UN, New York.

variable estimation using panel data, CEMFI Working Paper No. 9612 (Madrid: Centro des EstudiosMonetarios y Financieros).

Wade, R. H. (2004). Is Globalization Reduction Poverty and Inequality? World Development vol. 32 , No. 4 , pp. $567-589$.

Wawro, G. (2002). Estimating Dynamic Panel Data Models in Political Science, Journal of Political Analysis (2002) 10 (1): 25-48.

Woojin, K. and Katsushi, S.I. (2012). Pro-Poor Growth, Poverty and Inequality in Rural ietnam, Journal of Asian Economics 23(2012) 527-539.

World Bank (2013). World bank Annual Report 2013, World Bank Washington DC. United Nation Development Program (2013). Human Development Report (HDIs) 2013, UN, New York. 